\title{
Capital Transfer Outside Albania and the Absent Capital Market
}

\author{
Prof. Asoc. Dr. Elvin Meka \\ Deputy Dean and Head of Department of Finance, Faculty of Economy, European University of Tirana \\ elvin.meka@uet.edu.al
}

\section{Doi:10.5901/ajis.2015.v4n3s1p605}

\begin{abstract}
Capital outflows is beginning to attract the attention of policy makers, in the frame of stimulating investments within the country and furthermore, promoting lending to local business by commercial banks. The recent movement of the Albanian Parliament, by way of a special resolution of taking coercive actions by Bank of Albania, aiming at limiting capital outflows by commercial banks, is judged purely declarative and of good purpose only, without a real impact and value added, given the economic, political and strategic commitments, Albania has taken on international and European arena, the development of domestic economy and its model, and the stage of development and intermediation within the financial system and markets, as well as banking and non-banking sector. As per above, and in the context of an increasingly globalized world, and the Albanian's integration aspirations in the EU, imposing constraints, either administrative or in the form of tariffs and taxes on the free movement of capital, will complicate foreign investment climate in the country, in a time when several segments of the financial market, such as: capital market and private securities, remain fairly underdeveloped, thus limiting the investing useful and profitable alternatives for banks and other entities, with temporary surplus capital and funds, within the Albanian domestic market. Therefore, it is deemed necessary that policy-makers and regulatory \& oversight institutions for the Albanian financial system, must express and articulate a clear approach toward the TSE' revitalization, along with further deepening of the financial system, as the only way these segments of the financial system could make a contribution to alleviate and mitigate such an issue for the national economy.
\end{abstract}

\section{Introduction}

Several months ago (in June 2014), the Albanian Parliament adopted, unanimously, a resolution which among other things required the Bank of Albania to consider potential coercive measures, which should aimed at limiting the capital outflow (to be read here as temporarily idle funds) by commercial banks, in the form of investments or capital repatriation to parent banks. Moreover, the resolution encouraged and sought an even more active role of Bank of Albania itself, beyond restricting fund movements, in terms of investing them by banks, within the Albanian economy. By not going further about another request, addressed at Bank of Albania, to increase further its stimulus for the economy (indirectly implying a continuing cut in base interest rates), it is deemed as necessary addressing and explaining the main drivers, which are thought to have caused such move of the Albanian Parliament, which as a matter of fact, has not been articulated ever before and which represents a new approach towards foreign capital and investments in Albania.

The objective of the paper is to analyze the potential effects, the special resolution of the Albanian Parliament on coercive actions by Bank of Albania to limit capital outflows by commercial banks, on Albania's international obligations, as well as on the economic and financial development and foreign investments \& business climate. Additionally, the paper emphasizes the need for regulators and other groups of interest to consider measures and undertakings towards financial deepening, the development and functioning of Tirana Stock Exchange, as effective means to cushion the effects and consequences of capital outflows on real economy.

\section{Capital Outflows (Export) - Some Theoretical and Practical Considerations}

The debate about capital transfer and outflow, as well as its respective taxation or imposing limitations on their free movement is neither new, nor simple. According to Magud et.al (2014), capital controls is not a new topic in the international finance arena. Imposing and implementing capital controls seem to continue, nowdays, in various countries and within different economies, as well the academic and professional debate, about pros and cons of limiting the free movement of capital, since the collapse of the Bretton-Woods system, continuing during the globalization process, and especially following the Asian ciris of 1998 and recently in the aftermath of global economic \& financial crises of 20072008. 
McLeod (2002) affirms that, there is no widely accepted definition of capital flight. The classic use of the term is to describe widespread currency speculation, especially when it leads to cross-border movements of private funds that are large enough to affect national financial markets. The distinction between "flight" and normal capital outflows is thus a matter of degree, much like the difference between a "bank run" and normal withdrawals.

Also, Magud et.al (2014), stress that, the literature on capital controls has (at least) four very serious issues that make it difficult, if not impossible, to compare across theoretical and empirical studies, such as: (i) there is no unified theoretical framework to analyze the macroeconomic consequences of controls; (ii) there is significant heterogeneity across countries and time in the capital control measures implemented; (iii) there are multiple definitions of what constitutes a "success"; and (iv) the empirical studies lack a common methodology.

Liard-Muriente (2007) affirms that from one perspective, capital controls limit the ability of international financiers and multinationals to curtail labor. Among the economists promoting capital controls, Keynes was the most prominent. He was in favor of controls as a protective tool from the unstable international economy and the possibility of capital flight, which, among other things, causes a decrease in potential growth, erosion in the tax base, and redistribution from poorer to richer groups. However, from the neoclassical perspective, capital controls are just bad policies. They remove the discipline of the international market, which rewards countries that pursue pro-growth policies and penalizes those that do not. Also, controls hurt economic development and welfare. Nevertheless, history shows that governments use controls regularly. Capital controls are the set of regulations governing the movement of capital. Controls are set over both inflows and outflows, and within these two categories, as Nembhard (1996) explains, it is possible to have four additional subcategories: investment and credit regulation, trade restrictions, foreign exchange regulations and quantitative and tax policies. They may be applied in two forms: (1) as administrative measures on transactions and (2) taxes or tax-like measures on flows. Typically, according to Schuknecht (1999), tariffs on capital flows could be levied through noninterest-bearing reserve requirements (Chile had such requirements for a number of years but abolished them in September 1998). Also they could be levied as a proportionate tax on capital inflows and outflows, or as transaction taxes that aim to discourage short-term flows relative to long-term flow (the so-called "Tobin taxes", after James Tobin, the economist who first proposed them).

There may be different reasons for imposing capital controls, by different countries. As Liard-Muriente (2007) argues, countries often adopt controls to shelter the domestic economy from volatile capital movements, to regain policy autonomy, to allow domestic full employment and maximize social welfare, to save foreign exchange and to keep finances (domestic and international) under national control. Controls provide a second-best substitute for inadequate solvency supervision of banks and other financial institutions, reducing the size of volatile short-term foreign credits in relation to the economy.

\section{Capital Transfer and their Respective Control - Reasons And Consequences}

According to Forbes \& Warnock (2011), capital flow volatility can have widespread economic consequences, such as amplifying economic cycles, increasing financial system vulnerabilities, and aggravating overall macroeconomic instability. Also, the theoretical and empirical research reviewed here and in Section 2.1 suggests that a parsimonious list of the possible determinants of capital flow waves would include global factors such as global risk, liquidity, interest rates, and growth; contagion through trade linkages, financial linkages, and geographic location; and domestic factors such as a country's financial market development, integration with global financial markets, fiscal position, and growth shocks.

Nga ana tjetër, Magud et al (2014) propose four reasons (fears) which condition capital transfer (movement, and in turn the rationale for imposing or potential introduction of capital controls: (1) domestic currency appreciation/ depreciation, (2) hot money, (3) sheer volume investment flows and sudden injection of funds, which fuel asset price bubbles and encourage excessive risk taking by cash-rich domestic intermediaries and (4) loss of monetary autonomy.

\section{Albania and Its Respective Obligtions According to International Agreements}

The resolution of the Albanina Parliament is based upon a good intention to concede favors to national economy, whereas it stresses a justified concern and sensitivity in relation to the facts and realities, which are obviously noticed and observed, within Albanian banking system and crediting process in general, as well as ensuring optimal fundings for domestic businesses. However, should the resolution be set within the mosaic of the financial system and the free market, it is deemed as being destined to remain declarative, well-intended, but with no added value, in this regard. Specifically, the resolution should have considered and analyzed some essential facts and realities, related to economic, 
political and strategic commitments, Albania has assumed internationally and in an European context, the development of national economy and its model, the degree of development and intermediation within the financial market and system, or within the banking and non-banking sector, etc.

Firstly, Albania is a member of WTO, since 2000, and as such it can not impose discriminatory conditions and restrictions (i.e. can not violate the non-discrimination principle), including here restrictions on capital outflows and transfers. If such a measure is to imposed by the monetary authority, therefore it would be expected that other WTO members would respond in the same way, in relation to capital inflows towards Albania.

Secondly, the Republic of Albania signed the Stability and Association Agreement with the European Community and the Member Statesm and since 2010 Albania has fully liberalized its capital account, which is related with capital transfer nad investments abroad (towards EU). In this case, the Resolution practically contradicts some substantial obligations, Bank of Albania has undertaken, in the frame of SAA. Typically, point 3: "Capital movements and current payments", of Bank of Albania's obligations prescribes, inter alia, that:

With regard to transactions on the capital and financial account of balance of payments, from the date of entry into force of this Agreement, the Parties shall ensure the free movement of capital relating to credits related to commercial transactions or to the provision of services in which a resident of one of the Parties is participating, and to financial loans and credits, with maturity longer than a year. The Parties shall also ensure, from the fifth year after the date of entry into force of this Agreement, free movement of capital relating to portfolio investment and financial loans and credits with maturity shorter than a year.

Also, Albania and the European Community shall not introduce any new restrictions on the movement of capital and current payments between residents of the Community and Albania and shall not make the existing arrangements more restrictive.

In exceptional circumstances, movements of capital between the Community and Albania cause, or threaten to cause, serious difficulties for the operation of exchange rate policy or monetary policy in the Community or Albania, the Community and Albania, respectively, may take safeguard measures with regard to movements of capital between the Community and Albania for a period not exceeding one year if such measures are strictly necessary.1

According to Bank of Albania's reports, the situation within the Albanian financial system and the respective banking sector remains stable, given the recent hearing and reporting to the Albanian Parliament. In this regard, urging and encouraging Bank of Albania towards undertaking such a step is in conflict with SAA principles and requirements. Otherwise, to implement such measure, Bank of Albania must notify the existence of a certain situation in the banking system, that meets the criteria according to which Bank of Albania may take respective actions. On the other hand, even in case of undertaking such a measure, it would have a lifespan or 1 year only, that is, a simply stabilizing effect, whereas the resolution requires such a measure with the aim to encourage lending and investments within national economy. Strategically, at this point, it is deemed that Albania can not take steps back in this direction, at a time when a total, political and institutional commitment, towards EU membership, is critically required, more than ever.

Thirdly, funds invested by banks abroad are mainly placements in the form of deposits (time or checkable ones), as well as investments in foreign securities. This is a normal activity for banks around the world, in frame of a global world and finance, which is entirely consistent not only with the principles of makroprudentiality of banks in Albania, but also with the principle of efficient use of funds, borrowed from depositors and other lenders. In a time when, for a myriad of objective reasons, the national economy can not absorb the majority of available funds, banks have for lending, it seemed quite logical that they will seek other opportunities outside the Albanian financial market, which ensures more than $92 \%$ of financial intermediation through banks, and furthermore, with a total lack and absence of an established or formal and functioning capital market (stock exchange).

${ }_{1}$ Bank of Albania's website: http://www.bankofalbania.org/web/Mareveshja_Stabilizim_Asocim_2080_1.php and the Law No.9590, dated 27.07.2006: "On ratifying the Stability \& Association Agreement between the Republic of Albania and European Communitiess and their Member States", Article 57. 


\section{Exerpt from the article: \\ "LOOKING FOR INTERMEDIARIES", MONITOR Magazine, No.246, 2006}

Capital Account Liberalization brings foreign markets closer

Maybe we may not bave any securities (stock) exchange in Albania, but it will not binder, in the mid-term, non-bank financial institutions to intervene international markets, directly. Mr. Elsin Meka sajs that this move will be further accelerated by capital account Liberalization, starting from 2010, which will enable the Lff of barriers that are currently impased on capital export or tranffer. In the frame of use of funds, our country may be faced with a paradax, because it needs foreign capital injections instead of export them. "Maybe the jump of these institutions in the international market will weaken and scale back the funding potential of Albanian financial sector, as they will be free to invest wherever they see an interest in profits; should we bave a functioning and operating domestic securities market, such risk would have been smaller." By offering no alternative for any fund administration within country, these investors will soek and go after foreign markets, which are more matured, modern, well-estabtished and capable of offering many facilities.

Mr. Meka puts that, from a legal standpoint, the Albanian Financial Supervion Authority (AFS.A) may consider a review of licensing terms for now-bank financial institutions, aiming at increasing the minimum capital requirement, to create more value in assets. Meanwbile, the practice of use of funds according to international standards may be considered, some changes in the combasition of investment portfolio may be deemed as necessary, whereas a special consideration should be seriousty given to the fact that what kind of legislative initiatives should be taken, in the time when Albania liberalizes its capital account, because it needs a supervision harmonized with foreign standards and in cooperation with relevant bodies of the markets where these institutions do invest. The government may assist in accelerating of the operation of these markets througb relesant initiatives, by ensuring the technical infrastructure, products and the siability of securities.

Fourth, with regard to further monetary and crediting stimulus, several factors should be taken into account, which make difficult the effectiveness of monetary policy, implemented by Bank of Albania. The transmission mechanism of monetary policy in Albania, for some objective reasons, related to the shallowness of financial markets, lack of a basic and established capital market and the narrow range of tradable financial instruments (securities) in secondary markets, transmits (the Bank of Albania's monetary policy) with a relative time lag, usually after two-three quarters, within financial system and to the wider economy. This explains only one of several factors, affecting the slow effect, reflection and impact of Bank of Albania's decisions about changing the base interest rate. The other significant rationale is that risks inherent to the national economy, as well as in other countries of the region and in the world, are heightened, and this will be logically reflected to the entire structure of interest rates, banks charge for loans they grant. Currently, Bank of Albania is firing all it bullets (by cutting systematically the base interest rate), to enable an easing of lending process by banks, but Bank of Albania is not capable, even unilaterally, to reduce or moderate riska within the national economy. Its interventions are simply lowering the basis of the structure of bank loan interests, by allowing such structure to absorb increasingly additional risks in the economy. Consequently, the nominal level of interest rates for bank loans tends to move down not in tandem with the drop in base interest rate. Practically, the role of Bank of Albania in relation to the development of Ibanian financial market, starts to become increasingly limited and a further stimulus (lower interest rates) would produce less and less effect on bank loa's interest rates.

Fifth, the issues mentioned in the preceding paragraph reveals one of the structural problems of the Albanian financial system, that is the lack of an established capital (stock) market, and specifically the secondary market for private securities. The absence of an organized securities (stock) market, and the total lack of securities from the private sector and the modest trading activity of government papers (mainly those with over 1 year maturity) in the secondary market (as compared with primary market volumes), illustrate the shallowness of the Albanian financial market, and furthermore reveal the missing gears of a complete and efficient transmission mechanism of monetary policy by the country's monetary authority. In other words, Albania lacks the inter-sectoral competition (between banks and other nonbankfinancial institutions), which enables not only a real-time response to monetary policy, but above all, reduces costs of financial intermediation (interest rates).

As per above, it can be affirmed that, the capital export from banks in Albania has been, and it will be a normal phenomenon, which is likely to be further enlarged, as long as Albanian follows the current model of organizational and functioning structure of the financial system, which relies almost entirely and substantially on bank intermediation, with a complete absence of capital and securities (stock) market. The key element that must be clearly understood here is that, 
only the financial deepening and the establishment of a well-functioning capital market within Albanian economy will be capable to contribute (although initially in a modest way) in reducing the capital export, by channeling it through this market towards the public and private sector. Such an appeal is neither new, nor unheard, within the economy and financial system; on the contrary, for years and years it has been calling for the creation of necessary infrastructure and appropriate capital (securities) market, by not letting the issuance of private securities and listing of companies on the exchange, be developed on spontaneous grounds. Since 2006, I have been personally explained and called for such issues, whose effect, the role and impact will be materialized later (for more information see the BOX, depicting an excerpt from an article, addressing the issue of financial intermediaries, where among others, certain concerns have been raised about the possible capital export, following the capital account liberalization, as a result of the non-existence of a functioning stock exchange in Albania. Moreover, as noted by Stiglitz (1998), ...deep, efficient, and robust financial systems are essential for growth and stability. But left to themselves, financial markets will not become deep, efficient, or robust. The government plays an essential role, both in directly overseeing and regulating the financial system and also in establishing the correct incentives to encourage prudential and productive behavior".

Naturally, the establishment and the functioning of the stock exchange and the capital market in general will not be (and can not be) the center of gravity for national economy, but for an economy to provide sustainable growth and be developed away from (financial) systemic risks, it should be put on a right institutional, weel-regulated and properly supervised path. In this regard, a securities (stock) market and secondary functioning capital market (especially for private securities, but not only), will undoubtedly be a turning point for ensuring a more sustainable economic growth, an increase economy;s competitiveness in a regional scale and a greater stability within Albanian financial market. Postponing the issue of capital market does not solve the problem itself about such market, or that of the sizeable and continuing capital export.

In conclusion, it is deemed as necessary that policymakers and supervisory and regulatory institutions of the financial system, must express and articulate a clear will, toward the revitalization of Tirana Stock Exchange, whose wellfunctioning as a market and institution will be somehow contribute to alleviate such a problem for the economy. Ultimately, Baier, Dwyer and Tamura (2003) in their article: "Does Opening A Stock Exchange Increase Economic Growth?", put that: "...suppressing a stock exchange or impeding its operation is a good way to reduce economic growth"!

Furthermore, even Forbes \& Warnock (2011), stresses that, one country characteristic that has recently received substantial support in order to reduce this volatility-capital controls-does not significantly reduce the occurrence of surges, stops, or other capital flow episodes. Most of the significant drivers of capital flow volatility-such as changes in global risk, global growth, and contagion-appear to be outside the control of policymakers in most countries.

\section{Conclusions}

Imposing controls of capital outflows, gives an inhibiting signal for future foreign investment inflows, mainly in the financial and banking sector, along with contravening the international obligations, Albania has assumed to fulfill, as part of its integration agenda at European structures.

In a time when many segments of the Albanian financial market, such as: capital market and the market for private securities remain underdeveloped, the imposition of restrictions, either administratively or in the form of tariffs and taxes on free movement of capital, will complicate the climate of foreign direct investments, besides the fact that banks and other entities, with a temporary surplus idle funds, are faced with substantial lack of other investing and profitable alternatives in the Albanian financial market.

Policymakers and supervisory \& regulatory authorities of the Albanian financial system must articulate a clear will and approach, toward the revitalization of Tirana Stock Exchange, and further deepening of the financial system, as the only way such segments could somehow contribute to mitigate such the impact of this issue on national economy.

The government must focus on and further consider making efforts to strengthen the country's ability to cope with capital outflows' volatility, rather than simply trying to directly reduce such unpredictability, by imposing controls on capital flows.

\section{References}

Baier, S., Dwyer, Jr, G.P., \& Tamura, R (2003). "Does Opening A Stock Exchange Increase Economic Growth?", Fordham University, New York, CRIF Seminar series, Paper 28.

Dashi, L. (2006). "Looking for Intermediaries", MONITOR Magazine, No.246, f.19-22. 
Forbes, K. \& Warnock, F. (2011). "Capital Flow Waves: Surges, Stops, Flight, and Retrenchment", MIT Sloan School Working Paper 4927-11.

Liard-Muriente, C (2007). "Capital Controls: Theory and Practice", Journal of Business and Public Affairs, Volume 1, Issue 1.

Law No. 9590, dated 27.07.2006: "On ratifying the Stability \& Association Agreement between the Republic of Albania and European Communitiess and their Member States", Article 57..

Magud, N., Reinhart, C.M., Rogoff, K.S. (2014). "Capital Controls: Myth and Reality", American Economic Association.

McLeod, D. (2002). "Capital Flight", The Concise Encyclopedia of Economics, Library of Economics and Liberty. http://www.econlib.org/ library/Enc1/CapitalFlight.html

Nembhard, J. (1996). "Capital Controls, Financial Regulation, and Industrial Policy in South Korea and Brazil", Praeger, London.

Schuknecht, L., A (1999). "Trade Policy Perspective on Capital Controls", Finance \& Development, International Monetary Fund, Volume 36, Number 1.

Stabilisation and Association Agreement between the European Communities and their Member States, of the one part, and the Republic of Albania, of the other part., Official Journal of the European Union, 28.04.2009. http://ec.europa.eu/world/ agreements/downloadFile.do?fullText=yes\&treatyTransld=13127

Stabilization-Association Agreement: Bank of Albania's Obligations in the Stabilization-Association Agreemnt

http://www.bankofalbania.org/web/Mareveshja_Stabilizim_Asocim_2080_1.php

Stiglitz, J. (1998). "Sound Finance and Sustainable Development in Asia", Keynote Address to the Asia Development Forum, Manila, the Philippines. 


\title{
Microfinance as an Instrument in Financing the Rural Sector with an Impact on Poverty Reduction and Economic Development: Albanian Case
}

MSc. Adrian Muci

PHD Candidate, Faculty of Economy and Agribusiness (AU Tirana); Email: adrianmuci@yahoo.com

Dr. Fiqiri Baholli

Professor in the Faculty of Economy and Agribusiness (AU Tirana); Email: fbaholli@yahoo.com

Prof. Dr. Drini Salko

Professor in the Faculty of Economy and Agribusiness (AU Tirana); Email: dsalko@ubt.edu.al

\author{
Doi:10.5901/ajis.2015.v4n3s1p611
}

\section{Abstract}

An efficient rural financial market plays an important role in the development and growth of productivity in agriculture and livestock. This means setting up a financial system to meet the typical functions of a market economy and above all the mobilization and allocation of financial resources to this sector and coordination with sources of donors and of the state budget. In this context, perhaps it is useful to set up a bank profiled in agriculture and rural development, ending anarchy of today and by establishing opportunities for better coverage to the growing needs of this sector. This would help for the displacement of available funds to the agrarian sector, either through a specialized bank without curb or deter the existing commercial banks, and the combination with other efforts in the form of investment funds, would constitute a good opportunity for to finance agricultural development with nonpublic resources.

Keywords: microcredit, microfinance.

\section{Introduction}

Agricultural producer's opportunities for additional financial resources over the past two decades, faced a lot of constraints which have impacts on production, farm restructuring and investments to be carried out. These restrictions are a result of a combination of factors derived from the incomplete and costly information in rural financial markets and a number of specific problems that characterize the rural sector. An efficient rural financial market, plays an important role in the development and growth of productivity in agriculture and livestock. This means setting up a financial system to meet the typical functions of a market economy and above all the mobilization and allocation of financial resources of this sector and their coordination with donors and the state budget resources. On the other hand, the construction of an institutional framework that provides funding in accordance with the request of the rural sector is a necessary condition for the efficiency of the funding in this sector. Expansion and well-functioning farms and other agricultural activities, requires more than natural resources, requires financial resources to make these natural resources more efficient. Of the two main sources of capital, external and internal, domestic funds are the most important component. In most countries with low incomes and especially in periods of transition, financing through microcredit ${ }^{1}$ is dominant in the rural sector. Micro-credits granted to the rural sector, primarily aimed at reducing poverty and at a later stage the development of farmers economies affecting the pace of GDP growth in the sector.

In Albania already for more than two decades functions the microcredit market in the rural sector, with a dual economic and social impact; farm family poverty reduction and development and consolidation of farmers economies. One of the key monetary resources that would meet a substantial portion of funding for agriculture, are the savings of this

${ }^{1}$ The concept of microcredit was developed extensively for the first time by Muhammad Yunus, Nobel Prize winner in economics and founder of Grameen Bank, Bangladesh 